\title{
Child-related leave and women's labour market outcomes: towards a new paradigm in the European Union?
}

\author{
Author's first name: Miguel
}

Author's last name: de la Corte Rodríguez

Affiliation: Spanish Social Security Auditor working as a national expert for the Gender Equality Unit of the European Commission. He is also doing a joint $\mathrm{PhD}$ at the Catholic University of Leuven (KUL) and the Autonomous University of Madrid (UAM) under the supervision of Professors Paul Schoukens and Borja Suárez Corujo, entitled 'EU legislative framework on maternity leave: adoption of a multi-social risk approach?'. Responsibility for the information and views set out in this article lies entirely with the author.

Full postal address: Avenue Auguste Rodin 20, post box 10, 1050 Ixelles (Belgium)

Telephone number: 0032468327403

E-mail address: miguelcorte1981@yahoo.es 


\begin{abstract}
:
The current EU legislative framework on child-related leave is facilitating an imbalance in the take-up of leave by women over men. There is a consolidated EU right to maternity leave for mothers but there is no parallel EU right to paternity leave for fathers. The EU right to parental leave is for both working mothers and fathers, but its design does not encourage an equal take-up by women and men.
\end{abstract}

The aim of this article is to gain insight into the effects of child-related leave on women's labour market outcomes. On the one hand, it reviews and analyses economic literature which points to the adverse consequences of leave on women's earnings, and even on women's labour market participation when the absences from work are very prolonged. On the other hand, it underlines the new direction followed by the European Commission towards greater equality between men and women at home and at work.

Keywords: European Union law on child-related leave; maternity, paternity, adoption and parental leave; unequal distribution of caring responsibilities; women's labour market outcomes; inequality at work; Directive on work-life balance. 
Main text

\section{Introduction}

The current European Union (EU) law framework is facilitating an imbalance in the take-up of child-related leave by women over men. As acknowledged by the European Commission in its recent proposal for a Directive on work-life balance for parents and carers (COM (2017) 253 final), the current framework provides limited incentives for men to assume an equal share of caring responsibilities (recital 8). This framework, along with economic and cultural reasons ${ }^{1}$, explains why women keep on being the main takers of leave entitlements. The fact that women are the main leave takers may have a negative impact on their career prospects and wages. Moreover, this may affect the employability of every woman, regardless of whether they become a mother or not, as employers may prefer to hire men since they are less likely than women to take leave.

The aim of this article is to gain insight into the effects of child-related leave on women's situation in the labour market. It will take a multidisciplinary approach, which combines legal aspects, including EU Law and a comparative study of national legislation, with economic evidence. The main argument of this article is that an equal sharing of caring responsibilities is a precondition for achieving greater equality at work. The article will be divided into three sections. In the first section the EU law on child-related leave and the situation in some Member States will be presented in order to show to what extent the current state of affairs makes women more prone to take leave. The second section will carry out an economic literature review about the effects of leave on women's labour market outcomes, from both a theoretical and an empirical point of view. The last section will pay attention to the new direction followed by the European Commission aimed at encouraging a more balanced takeup of leave arrangements by men and women and improving women's access to and position in the labour market.

\section{EU law on child-related leave}

There are currently different categories of child-related leave in the EU that help workers reconcile their professional and family responsibilities. The main ones are maternity leave, paternity leave, adoption leave and parental leave. These periods of leave are to some extent regulated at EU level. To be more precise, EU law lays down minimum requirements as set 
out in Article 153(2)(b) of the Treaty on the Functioning of the EU and Member States can always adopt more generous measures. At national level there may be other kinds of leave that will not be addressed in this article, such as breastfeeding breaks and leave to look after sick children. For the four kinds of leave studied here, the situation of four Member States will be described, namely Belgium (BE), Spain (ES), Ireland (IE) and the United Kingdom² (the UK). These countries illustrate systems with a short maternity leave and a long parental leave (BE and ES) and, conversely, also schemes with a long maternity leave and a short parental leave (IE and the UK).

\section{Maternity leave}

The right to paid maternity leave is recognised as a fundamental right in Article 33(2) of the Charter of Fundamental Rights of the EU (CFREU). Maternity leave is the period off work granted to working mothers around the time of childbirth, during pregnancy and after delivery, which according to long standing case law of the Court of Justice of the EU (CJEU) serves different purposes: the protection of the delivering mother's biological condition during pregnancy and after giving birth and the protection of the special relationship between the mother and her newborn after childbirth (the most important judgments are: C-184/83 Hofmann ECLI:EU:C:1984:273; and C-5/12 Betriu Montull ECLI:EU:C:2013:571). This leave is harmonised in the EU through two Directives, namely the Pregnant Workers Directive (PrWD) (Directive 92/85/EEC of 19 October 1992 on the introduction of measures to encourage improvements in the safety and health at work of pregnant workers and workers who have recently given birth or are breastfeeding OJ L 348), applicable to employees, and the Self-Employment Directive (SED) (Directive 2010/41/EU of 7 July 2010 on the application of the principle of equal treatment between men and women engaged in an activity in a self-employed capacity OJ L 180), relevant for independent workers. These Directives focus primarily on the first of the purposes just mentioned.

The PrWD entitles female employees to a statutory continuous period of maternity leave of at least 14 weeks allocated before and/or after confinement, which must include a compulsory period of at least 2 weeks allocated also around confinement. This right is ensured by several measures, such as the maintenance of an adequate income at least equivalent to the national sickness allowance and the maintenance of other employment rights during maternity leave and the prohibition of dismissal from the beginning of pregnancy to the end of maternity 
leave. With reference to the maintenance of rights, Barnard (2012, p. 412) acknowledges that 'the (major) exception to the rule that a woman's rights connected with the contract of employment must be maintained relates to pay'. Indeed, during maternity leave full pay is not guaranteed. The PrWD only ensures that the worker receives an income equivalent to the national sickness allowance. For its part, the SED entitles female self-employed workers to a sufficient maternity allowance (as defined in its Article 8) enabling interruptions in their occupational activity owing to pregnancy or motherhood for at least 14 weeks.

For the four Member States studied, the duration of the leave for employees ranges from relatively short periods -15 weeks in BE and 16 in ES- to long periods of leave -42 weeks in IE and 52 in the UK. For self-employed workers, the duration is generally shorter, ranging from 12 weeks in BE and 16 in ES to 26 weeks in IE and 39 in the UK. The compulsory periods of maternity leave are short, from 2 to 6 weeks around the time of childbirth -3 weeks in BE for self-employed workers (1 before and 2 after birth), 6 after-birth weeks in ES, 6 weeks in IE ( 2 before and 4 after birth) and 2 after-birth weeks in the UK for employees (4 if the employee works in a factory). The only exception is the 10 -week obligatory period in BE for employees (1 week before and 9 weeks after birth). Concerning the maintenance of income, all countries grant social security allowances, except in the case of employees in the $\mathrm{UK}$, for whom a payment is made by the employer (but employers can claim back the sum paid from the Exchequer). However, it has to be underlined that some periods of maternity leave are unpaid for employees, namely 16 weeks (out of 42) in IE and 13 weeks (out of 52) in the UK. With respect to the level of income replacement, there are three different systems: first, based on earnings in BE for employees and in ES- in BE 82\% of earnings, without a ceiling, during the first 30 days of maternity leave, and $75 \%$ with a ceiling for the remaining period, and in ES $100 \%$ of earnings, with a ceiling; second, a flat-rate amount in BE for independent workers, in IE, and in the UK for self-employed workers -currently 475.41 euros per week in BE, 235 euros per week in IE, and 140.98 pounds (160 euros) per week in the UK; thirdly, a combination of the two in the UK for employees -6 weeks at $90 \%$ of earnings (without a ceiling) and 33 weeks at (currently) 140.98 pounds (160 euros) per week.

Although the right to maternity leave is a right of the delivering mother, in ES and the UK she may decide that the working father will take all or part of the voluntary period of maternity leave. This practice has been upheld by the CJEU in the Betriu Montull case (paragraphs 56 and 58). In ES the mother may decide to transfer completely or partly the 
voluntary weeks of maternity leave to the father (up to 10 out of 16). In the UK it is possible to transform wholly or partly the voluntary weeks of maternity leave (up to 50 out of 52) into shared parental leave if the delivering employee chooses to do so. In this case, the two parents can access the shared parental leave. Despite these provisions, maternity leave continues to be overwhelmingly taken by mothers. In ES official statistics show that fathers benefited from the maternity allowance in 2017 in less than $2 \%$ of cases $^{3}$ and several studies show the low take-up of the shared parental leave scheme in the $\mathrm{UK}^{4}$.

A summary of the main features of the different systems of maternity leave for employees can be found below:

\begin{tabular}{|l|l|l|l|l|}
\hline System & Duration & Compulsory period & Paid period & Level of payment \\
\hline EU & 14 weeks & 2 weeks & 14 weeks & National sickness allowance \\
\hline BE & 15 weeks & 10 weeks & 15 weeks & $82 \%$ and $75 \%$ of earnings \\
\hline ES & 16 weeks & 6 weeks & 16 weeks & $100 \%$ of earnings \\
\hline IE & 42 weeks & 6 weeks & 26 weeks & Flat-rate \\
\hline UK & 52 weeks & 2 weeks & 39 weeks & $90 \%$ of earnings and flat-rate \\
\hline
\end{tabular}

\section{Paternity leave and adoption leave}

Paternity leave and adoption leave are to some extent regulated by EU Law in Article 16 of the Recast Directive (Directive 2006/54/EC of 5 July 2006 on the implementation of the principle of equal opportunities and equal treatment of men and women in matters of employment and occupation OJ L 204). This Article does not create EU rights to paternity and adoption leave, which means that the recognition of these rights is up to the Member States. However, those Member States which recognise such rights must protect working men and women against dismissal due to exercising those rights. In addition, Member States shall also ensure, as a corollary to the protection against dismissal, that, at the end of paternity and adoption leave, workers are entitled to return to their jobs or to equivalent posts on terms and conditions which are no less favourable to them, and to benefit from any improvement in working conditions to which they would have been entitled during their absence. With regard to paternity leave, Caracciolo di Torella (2014. p. 101) criticises the fact that, unlike maternity leave, the EU has construed "fathers" rights as an option for Member States to consider, rather than an individual right'. 
Neither paternity leave nor adoption leave are defined in the Recast Directive. Nevertheless, their features can be deducted from some of its provisions. Concerning paternity leave, recital 26 affirms that Member States were encouraged to consider examining the scope for their respective legal systems to grant working men an individual and non-transferable right to paternity leave. Thus, recital 26 makes clear the persons entitled (individual right of working men) and the non-transferability feature. With regard to adoption leave, recital 27 refers to the granting by Member States to men and women of an individual and non-transferable right to leave subsequent to the adoption of a child. This leave to some degree replicates maternity leave by replacing childbirth with the entry into adoption. However, as adoption leave is not connected to the biological condition of the mother, the purpose of the leave is solely the care of adopted children just after their adoption. That is why this is an individual and nontransferable right of the two working parents, men and women.

In the Member States analysed paternity leave is granted in the case of birth to the working father, employees (BE and the UK) or both employees and independent workers (ES and IE). The duration of paternity leave is rather short, ranging from 2 weeks in BE (10 working days), IE and the UK to 4 weeks in ES. Paternity leave can be taken during a defined period after childbirth: 56 days in the UK, 4 months in BE, during maternity leave or just after it in ES and 28 weeks in IE. It seems then that paternity leave is the male counterpart of maternity leave, that is to say a right of the working father to be used after childbirth to take care of the newborn. However, there is a prominent difference between these two leaves: their duration. Paternity leave is compensated at the same level as maternity leave with the exception of the UK, where the leave is paid straightaway by the employer at a flat-rate of 140.98 pounds (160 euros) - maternity leave is paid at $90 \%$ of earnings (without a ceiling) for the first 6 weeksand $\mathrm{BE}$, where the leave is paid by the employer at $100 \%$ of earnings for the first 3 days and by social security at $82 \%$ (with a ceiling) for the last 7 days. Caracciolo di Torella (2007, p. 322 ) is of the opinion that paternity leave legislation in the UK 'is drafted in such a way to reinforce the idea that mothers rather than fathers are the primary carers. Indeed fathers $[\ldots]$ are not entitled to the same (salary related) level of pay. Finally, their right is limited to 'up to two weeks' rather than the 12 months potentially reserved to the mother'. Likewise, WeldonJohns (2011, p. 29) states that 'the dominance of maternal rights is [...] apparent in the length of maternity leave which extends much further than the original focus on the post-birth period and arguably extends into early childcare'. 
A summary of the main features of different systems of paternity leave for employees can be found below:

\begin{tabular}{|l|l|l|}
\hline System & Duration & Level of payment \\
\hline BE & 2 weeks & $100 \%$ and $82 \%$ of earnings \\
\hline ES & 4 weeks & Same as for maternity leave \\
\hline IE & 2 weeks & Same as for maternity leave \\
\hline UK & 2 weeks & Flat-rate \\
\hline
\end{tabular}

Regarding adoption leave, despite what is prescribed in the Recast Directive, at national level only BE grants an individual and non-transferable entitlement to each working parent. In ES, adoption leave is conceived of as a family entitlement, while in IE and the UK only one adopter is entitled (with a legal preference for the adopting mother in IE). For economic and cultural reasons, such a legal design of the entitlement to adoption leave makes women more likely than men to make use of it $^{1}$. As for the duration of adoption leave, in three of the four countries (ES, IE and the UK) it mirrors exactly the duration of the post-birth period of maternity leave. In ES and the UK, which do not have compulsory periods before birth, the length of adoption leave is the same as that of maternity leave: 16 weeks in ES and 52 weeks for employees in the UK (self-employed workers are not entitled to adoption leave). In IE, which has a 2-week compulsory period before birth, the duration of adoption leave is precisely 2 weeks less than that of maternity leave (40 weeks for employees and 24 weeks for independent workers). In BE the global duration of adoption leave (12 weeks, 6 for each parent) mirrors roughly the length of the post-birth period of maternity leave (up to 14 weeks for employees and up to 11 for self-employed workers). Regarding the maintenance of income, some periods of adoption leave are unpaid for employees, namely 16 weeks (out of 40) in IE and 13 weeks (out of 52) in the UK. The level of income replacement is the same as for maternity leave with the exception of BE for employees, where adoption leave is paid by the employer at $100 \%$ of earnings for the first 3 days and by social security at $82 \%$ (with a ceiling) for the remaining period. 
A summary of the main features of the different systems of adoption leave for employees can be found below:

\begin{tabular}{|l|l|l|l|l|}
\hline System & Entitlement & Duration & Paid period & Level of payment \\
\hline BE & $\begin{array}{l}\text { Individual and } \\
\text { non-transferable }\end{array}$ & $\begin{array}{l}12 \text { weeks (6 for } \\
\text { each adopter) }\end{array}$ & 12 weeks & $100 \%$ and $82 \%$ of earnings \\
\hline ES & Family entitlement & 16 weeks & 16 weeks & Same as for maternity leave \\
\hline IE & Only one adopter & 40 weeks & 24 weeks & Same as for maternity leave \\
\hline UK & Only one adopter & 52 weeks & 39 weeks & Same as for maternity leave \\
\hline
\end{tabular}

\section{Parental leave}

As with maternity leave, parental leave is recognised as a fundamental right in Article 33(2) of the CFREU. This leave is also harmonised at EU level, this time through a Directive applicable only to employees, i.e. the Parental Leave Directive (PLD) (Directive 2010/18/EU of 8 March 2010 implementing the revised Framework Agreement on parental leave OJ L 68). Parental leave is a right of working parents, male or female, entitling them to at least 4 months' leave with a view to ensuring the care of natural and adopted children until a given age (to be defined by Member States) up to 8 years old. This leave is often taken once the maternity/paternity/adoption leave period has expired (where paternity and adoption leave is provided at national level). Although parental leave is an individual entitlement, it can be transferred from one parent to the other, except for 1 month which is reserved for each parent. In this sense, the Directive acknowledges that making the leave non-transferable can act as a positive incentive for the take up by fathers (recital 16 of the Annex). However, Member States are free to decide that the rest of the parental leave period can be transferred from one parent to the other (in practice mostly from the father to the mother).

The right to parental leave is safeguarded by several measures, such as the maintenance of rights acquired or in the process of being acquired on the date on which parental leave starts until the end of parental leave, protection against less favourable treatment or dismissal on the grounds of an application for, or the taking of, parental leave and the right to return to the same job. Yet, currently Member States are free to decide whether and to what extent income is maintained during parental leave. The lack of income-replacement during parental leave has been censured by several authors, above all because this leads to a gender-unequal use of the leave. Caracciolo di Torella (2014, p. 98) holds that the main problem of the PLD 'was 
the lack of remuneration: it therefore failed to attract interest amongst fathers reluctant to give up the (usually) higher family income'. By the same token, Currie (2013, p. 395) sustains that 'the usefulness of this Directive in truly facilitating reconciliation for fathers is uncertain'.

In the Member States under study only employees are entitled to parental leave. Comparing the parental leave available, it is possible to visualise two groups of countries. The first group (BE and ES) has a somewhat long parental leave: 16 months in BE (4 months of "parental leave" until the child is 12 years old plus 12 months of "time credit system" for a child younger than 8) and up to 3 years in ES (the 3 years following the birth or adoption of a child). Conversely, the second group of countries (IE and the UK) has a minimalistic 18week parental leave (in the UK until the child is 18 years old and in IE until the child is 8 years old). In the four countries parental leave is designed as a non-transferable individual entitlement, except for IE when both parents work for the same company, in which case 14 weeks are transferable. However, only in BE is parental leave paid. "Parental leave" is compensated by social security at a flat-rate of 818.56 euros per month and the "time credit system" at a flat-rate of up to 667.28 euros a month.

A summary of the main features of the different systems of parental leave can be found below:

\begin{tabular}{|l|l|l|l|l|}
\hline System & Duration & Non-transferability & Paid period & Level of payment \\
\hline EU & 4 months & 1 month & None & - \\
\hline BE & 16 months & 16 months & 16 months & Flat-rate \\
\hline ES & 3 years & 3 years & None & - \\
\hline IE & 18 weeks & 18 weeks & None & - \\
\hline UK & 18 weeks & 18 weeks & None & - \\
\hline
\end{tabular}

\section{Effects of child-related leave on women's labour market outcomes}

The effects of child-related leave on women's labour market outcomes have been studied in economic scholarship. Economically speaking what matters is the different interruptions of work related to children with job protection, and sometimes income support, and the way these interruptions affect the labour market outcomes of women, who continue to be the main takers of leave entitlements. 
This section is divided into two parts. In the first part the economic theory on the markets for labour and the expected effects of child-related leave on women's labour outcomes will be presented. The second part will cover the empirical literature to see the extent to which economic theory predictions fit with empirical results.

\section{Economic theory}

The markets for labour are driven by two forces, supply and demand. It has to be noted that, in economics, firms are on the demand side, because they are the ones that buy labour, and households are represented as suppliers of labour (Dorman, 2014, p. 339). Equilibrium $\left(\mathrm{E}_{0}\right)$ in the labour market is reached where the aggregate of the firm-level demand curves and the aggregate of individual supply curves juxtapose (figure 1), at the wage rate $\mathrm{W}_{0}$ and the number of workers $\mathrm{L}_{0}$. It has to be noted that the graphs represented in this sub-section, which have been prepared by the author, are based upon a perfectly competitive labour market which relies on heavy assumptions ${ }^{5}$. They are a simplification of reality to help theoretically understand how an external factor, all others things being equal or held constant, affects the wage rate and the number of workers. Therefore, these graphs should be regarded merely as pedagogic tools for understanding markets for labour.

Figure 1: equilibrium in the labour market

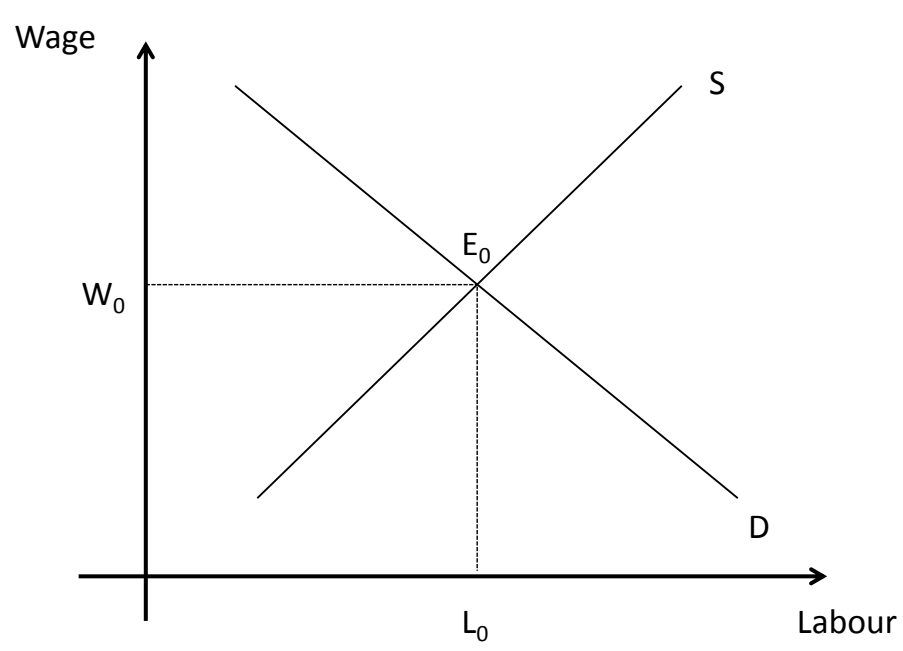

The current review of economic scholarship shows that the effects of child-related leave are neither simple nor linear. According to Hanel (2013, p. 340), 'from a theoretical point of view these effects are ambiguous'. For instance, the interruptions of work of an employee on leave could reduce their labour productivity via the deterioration of skills, but at the same time the return to work (thanks to job protection) may increase such productivity through the 
retention of human capital. Additionally, following Thévenon and Solaz (2013, p. 26), 'the effect of the duration of parental paid leave might not be linear. A short period of leave, for example, is expected to have a positive influence on employment rates, whereas a negative or lesser effect may arise from long leave entitlements'.

\section{Expected effects of leave on the labour demand curve}

Child-related leave may affect labour demand in a twofold way. Firstly, the entitlements to leave may cause an increase in costs for the employer who has to seek, train and pay a presumably less productive employee to replace the worker on leave. In turn, this could shift the labour demand curve to the left. Secondly, as stated above, labour productivity of the worker on leave may either shift the labour demand curve to the left if a depreciation of human capital occurs or to the right if human capital is enhanced.

With regard to the costs of child-related leave for the employer, wage costs and non-wage costs can be differentiated. "Wage costs" refer to the payment of leave benefits by the employer, or in the words of Scheubel $(2014$, p. 2) to 'the direct pecuniary cost of financing maternity pay'. However, this payment is not common in Europe since leave benefits are paid primarily by the government in most European countries ${ }^{6}$. "Non-wage costs" are the expenses associated with hiring and training temporary replacement workers. Thévenon and Solaz (2013, p. 18) consider that 'the provision of leave raises the non-wage costs of labour if employers need to change the production process or hire, and possibly train, temporary staff'.

As pointed out by Thévenon and Solaz, employers may 'grow disinclined to recruit female workers' to avoid the costs of child-related leave (2013, p. 18). Furthermore, Schönberg and Ludsteck (2014, p. 470) affirm that 'employers may respond by hiring fewer women or by lowering their wages'. Graphically, these ideas are represented as a shift to the left of the labour demand curve (figure 2). 
Figure 2: Shift in the labour demand curve due to the costs of child-related leave

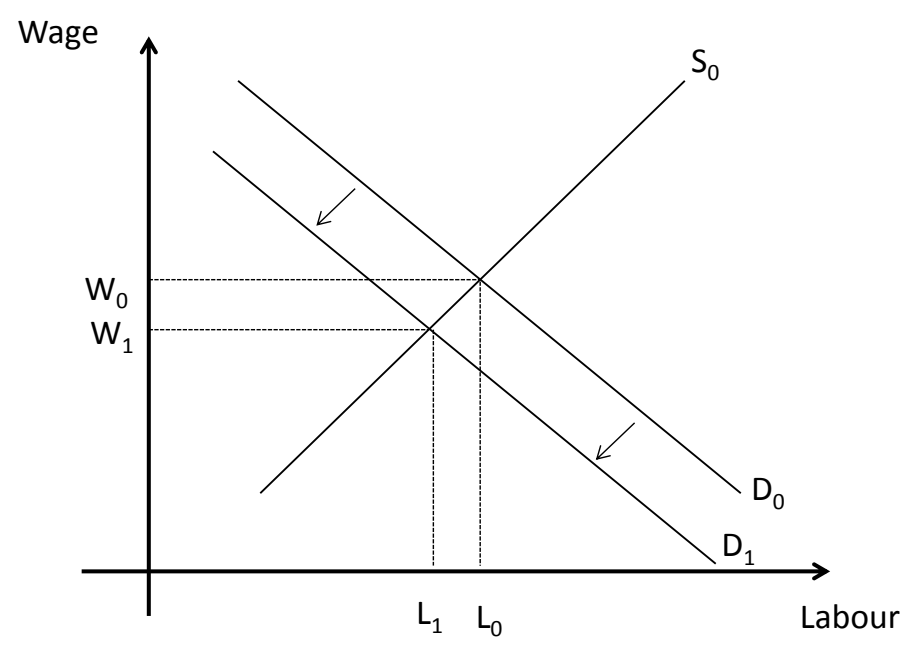

The effects of child-related leave on labour productivity are not as straightforward. On the one hand, following Jacobi, Wagner, and Frühwirth-Schnatter (2014, p. 2), 'this break is likely to lead to a depreciation of general and firm-specific skills during absences from the labor market and lost rents associated with good job matches'. Additionally, del Boca, Pasqua and Pronzato (2009, p. i155) highlight that 'the longer women stay out of the labour force, the greater the deterioration of their skills and the loss of opportunities for promotion and training'.

On the other hand, as affirmed by Ruhm (1998, p. 290), 'labour productivity will rise if parental leave increases firm-specific human capital by allowing individuals to return to their old jobs'. Similarly, Ramírez Bustamante, Tribin Uribe and Vargas (2015, p. 14) argue 'that those with maternity leave have a higher probability of going back to work after enjoying the maternity leave period, which is beneficial for the firm as long as it can retain a person that already has specific knowledge about the firm'.

All things considered, if the overall effect on labour productivity is negative the labour demand curve will shift to the left $\left(\mathrm{D}_{1}\right)$. Otherwise, the labour demand curve will shift to the right $\left(\mathrm{D}_{2}\right)$ (figure 3$)$. 
Figure 3: Shift in the labour demand curve due to the changes in labour productivity related to child-related leave

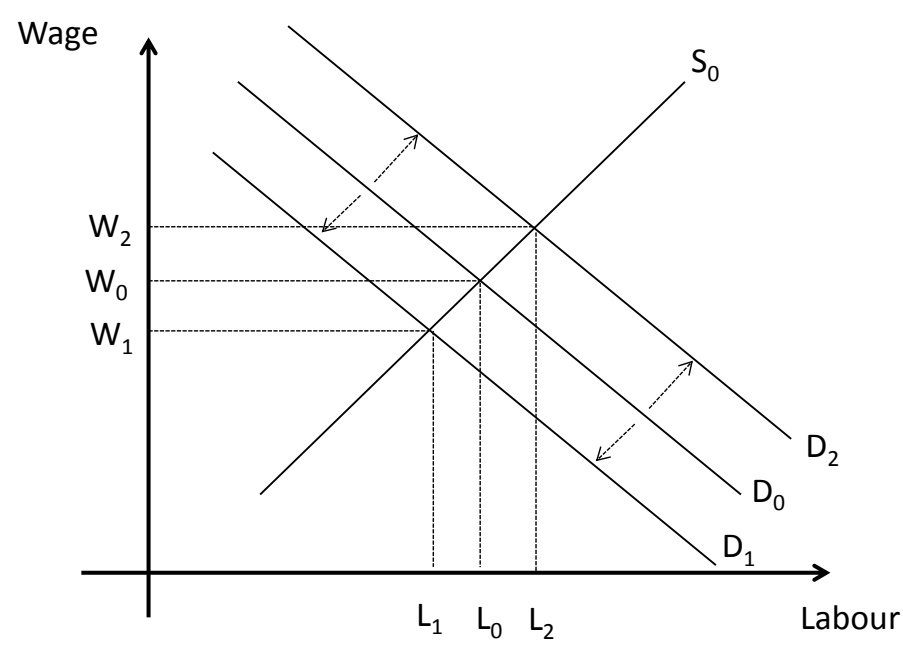

Expected effects of leave on the labour supply curve

Child-related leave can also affect the labour supply curve. First of all, it could act as an incentive for labour market participation for those women who could eventually be entitled to leave. If so, there will be an increase in women's labour supply. Secondly, the immediate effect of child-related leave is a reduction in the labour supply because leave-takers stop working during the periods of leave, at least economically-speaking. Yet, these entitlements may also increase the labour supply if the absences from work would have been longer had child-related leave not existed.

Expectations about child-related leave entitlements (introduction or increase of leave) are expected to increase women's incentives to participate in the labour market. Rønsen and Kitterød (2015, p. 60) are of the opinion that child-related leave increases women's attachment to the labour market 'by giving future mothers strong incentives to be employed prior to birth in order to qualify for benefits'. Thévenon and Solaz (2013, p. 18) explain that 'because women are more likely than men to claim all their leave entitlements, their labour supply curve will rise slightly'. Graphically (figure 4), the labour supply curve will move to the right. 
Figure 4: Shift in the supply curve due expectations about child-related leave entitlements

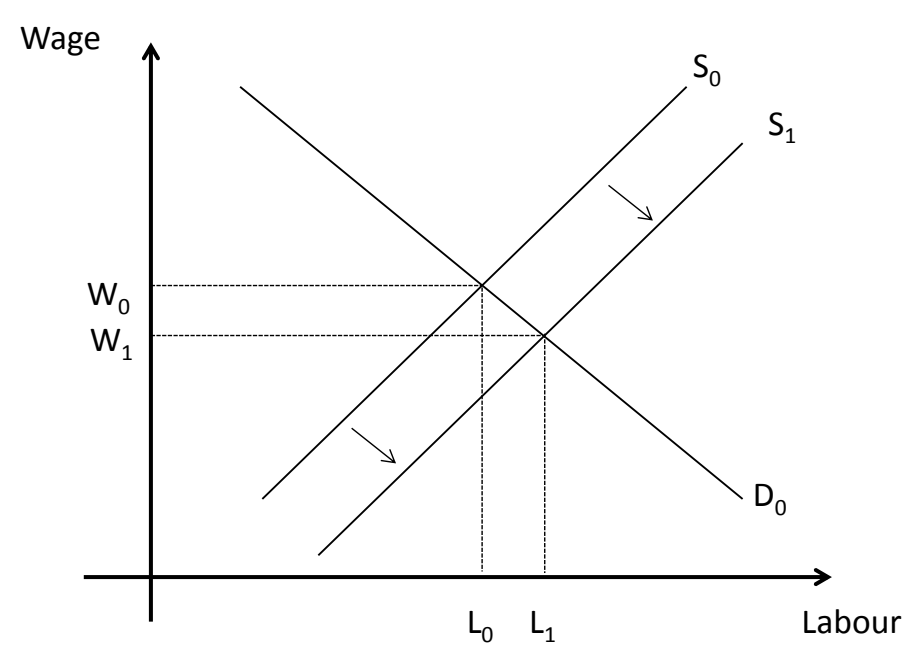

Concerning the incidence of child-related leave on the absences from work, it has to be clarified first that in purely economic terms these absences are non-work periods. However, one should be aware that they are often considered as periods of work for employment statistics and sometimes also for legal purposes (for instance, accrual of labour and social security rights).

Unlike the clear-cut effects of expectations about leave entitlements, the effects of absences from work due to child-related leave are equivocal. On the face of it, it seems obvious that these interruptions of work reduce the women's labour supply. Thévenon and Solaz (2013, p. 18) affirm that 'access to leave is what first encourages women to take short career breaks these interruptions of employment not being always reported in employment statistics'. However, the fundamental question here is whether the interruptions of work would be longer in the absence of child-related leave. If the answer is negative, child-related leave would encourage longer absences from work and reduce women's labour supply accordingly. If the answer is positive, child-related leave would imply shorter interruptions and an increase in women's labour supply.

All in all, if child-related leave implies more absences from work the labour supply curve will shift to the left $\left(S_{1}\right)$. If not, the labour supply will shift to the right $\left(S_{2}\right)$ (figure 5). 
Figure 5: Shift in the supply curve due to absences from work related to child-related leave

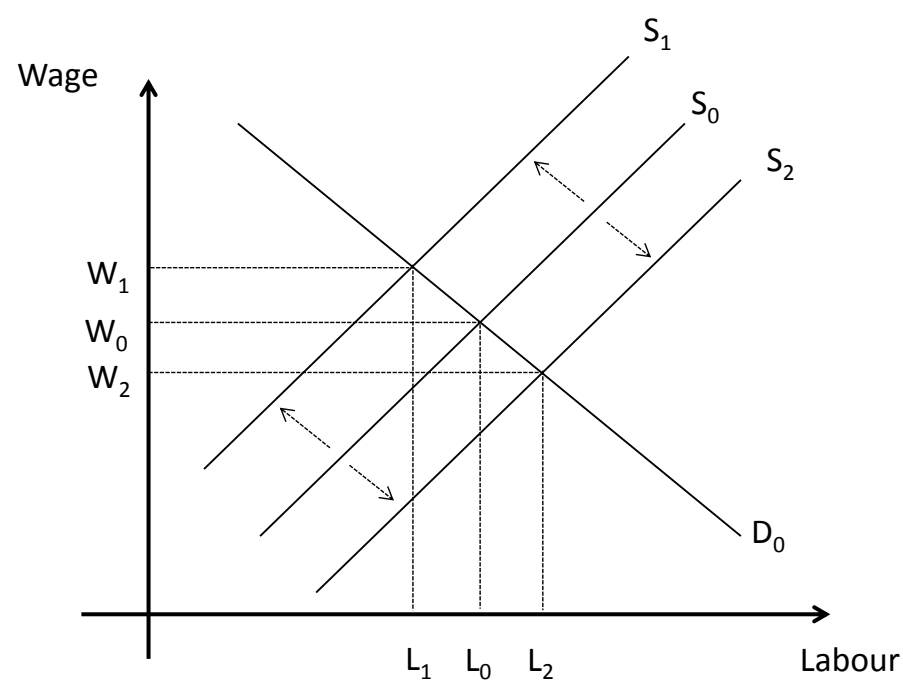

Ruhm's equilibrium: a possible scenario

Ruhm (1998, p. 289-290), before pursuing his empirical analysis, made a guess about the possible overall consequences of child-related leave on women's labour market outcomes (figure 6). He expects the labour supply curve to move to the right $\left(S_{1}\right)$ thanks to the higher expectations of women to participate in the labour market. Simultaneously, the demand curve moves to the left due to the costs of child-related leave for the employer. However, as in Europe benefits are primarily paid by social security administrations, demand will only shift to the extent that non-wage costs increase $\left(D_{1}\right)$. As a result, according to Ruhm, the shift in supply is likely to be larger than the shift in demand, implying that the employment of women will rise $\left(\mathrm{L}_{1}\right)$ and their wages will fall $\left(\mathrm{W}_{1}\right)$ in the new equilibrium $\left(\mathrm{E}_{1}\right)$. 


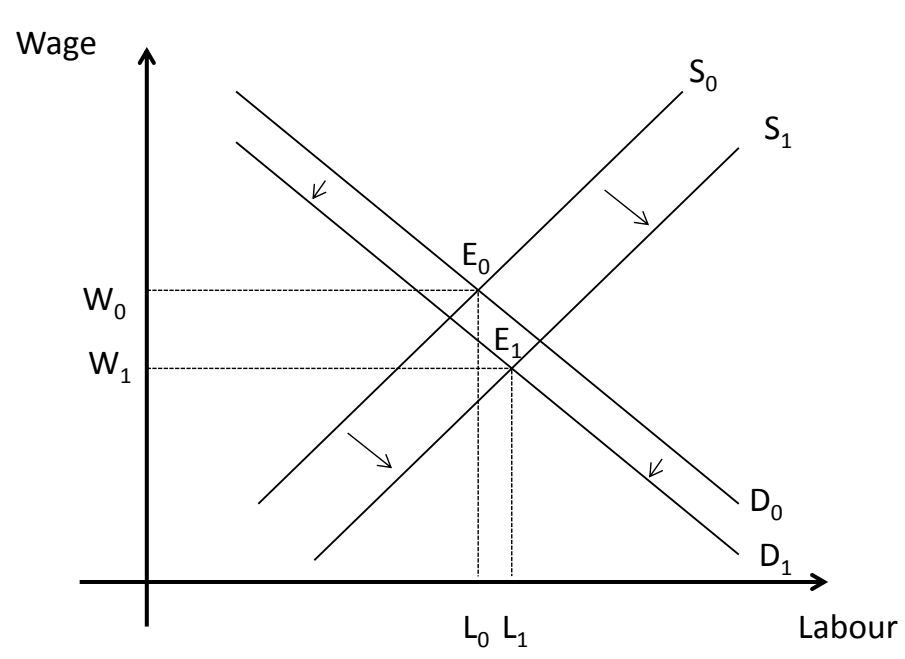

\section{Empirical literature}

This part will review some empirical studies which analysed the effects of child-related leave on women's labour market outcomes to assess the extent to which reality fits with economic theory predictions. Although there is extensive research at national level, only international studies will be reviewed here. First, the ones that pay attention exclusively to child-related leave will be presented. Next, the ones which cover several institutional factors that may influence women in the labour market will be analysed. Besides child-related leave, other public policies also exist, such as child-care facilities or part-time working arrangements. However, the emphasis will be put on results related to child-related leave.

\section{Studies focused on the effects of child-related leave}

There are three main international studies which focus on child-related leave, two of them at European level and another one at the level of the Organisation for Economic Co-operation and Development (OECD).

Ruhm's pioneering study (1998) investigates the labour market consequences (employmentto-population ratios and hourly wages) of rights to paid child-related leave using data for 9 European countries (Denmark, Finland, France, Germany, Greece, Ireland, Italy, Norway and Sweden), from 1969 to 1993 . Although this study is rather old, it remains a valid reference point on which other economists have built their research. 
As regards employment-to-population ratios, this article shows that leave legislation raises the female employment-to-population ratio by between 3 and 4 percent, with larger effects for women in their prime childbearing years (25-34 year old women). However, this increase may be overestimated since European countries often count individuals on parental leave as "employed but absent from work" rather than "not employed". Ruhm reckons that from onequarter to a half of the increase is probably due to the number of women who are reclassified as "employed but absent from work" due to the availability of leave. Concerning hourly wages, brief leave entitlements (3 months) have little effect on women's earnings, but lengthier leave is associated with substantial ( 2 to 3 percent) reductions in relative wages. In Ruhm's words, 'to summarize, this study indicates that parental leave guarantees raise the employment of women but, at longer durations, may be paid for through the receipt of lower relative wages' (1998, p. 315).

Akgunduz and Plantenga's study (2013) is a follow-up of Ruhm's article, which integrates more countries and a longer period of time. Specifically, they analyse the effects of the weighted duration of maternity and parental leaves (duration weighted with the income replacement rate) on women's labour market outcomes (employment rates, hours worked, wages and vertical occupational segregation) in 16 European countries (EU-15 and Norway) from 1970 to 2010 .

The article finds positive effects on employment rates and hours worked (optimal amount around 30 weeks) and negative effects on wages of highly-skilled workers and vertical occupational segregation (share of women in high-level occupations). Compared to Ruhm's previous estimations, the results suggest a slightly lower increase in employment accompanied by a larger decrease in high-skill wages, while the negative effect on low-skill wages becomes insignificant. The authors apply their results to the EU legislation and argue that 'the case for extending minimum parental or maternity leave is not strong from a purely labour market perspective. The current legislation of 14 weeks of paid maternity leave and 12 weeks of supplementary parental leave [the old PLD 96/34 provided an EU minimum period of parental leave of 3 months] seems to capture most of the positive effects for participation rates. Anything beyond the current minimum is likely to have minimal impact on participation while potentially decreasing wages and causing occupational segregation' (Akgunduz and Plantenga, 2013, p. 860). 
As with Akgunduz and Plantenga's study, the article by Thévenon and Solaz (2013) also builds on the framework proposed by Ruhm. However, the geographical coverage is even larger as it incorporates non-European countries. In particular, this article analyses the effects on 25-54 year old women's labour market outcomes (employment rates, average working hours and earnings of full-time employees) of paid child-related leave in 30 OECD countries (Australia, Austria, Belgium, Canada, Czech Republic, Denmark, Finland, France, Germany, Greece, Hungary, Iceland, Ireland, Italy, Japan, Korea, Luxembourg, Mexico, Netherlands, New Zealand, Norway, Poland, Portugal, Slovakia, Spain, Sweden, Switzerland, Turkey, the United Kingdom and the United States of America) from 1970 to 2010.

The article finds that overall the provision of paid leave has a positive effect on the employment rates and average working hours of prime-age women. However, extending paid leave beyond 2 years has counterproductive effects on female employment rates and average working hours. As regards earnings, the provision and gradual lengthening of paid leave have contributed to a widening in the gender pay gap of full-time employees. Compared with Ruhm's findings, Thévenon and Solaz's study 'confirms that the provision of a relatively short period of paid leave reduces the gender employment gap, but prolonged periods of leave have the opposite effect. By contrast, short and long periods of paid leave contribute to gender pay gaps, also of full-time employees' (2013, p. 40).

\section{Studies on the effects of institutional factors in general}

Four international studies that cover several institutional factors that may influence women in the labour market are going to be reviewed.

Firstly, Genre, Gómez Salvador and Lamo (2010) analyse the factors (individual preferences, namely fertility and education enrolment, or labour market institutions, among them childrelated leave, childcare services and part-time work) that influence the evolution of female participation rates in the labour market in 12 of the EU-15 (Belgium, Denmark, Finland, France, Germany, Ireland, Italy, Netherlands, Portugal, Spain, Sweden and the United Kingdom) from 1980 to 2000, for three different groups: 15-24, 25-54 and 55-64 years old.

The article discards any doubt on the influence of institutions on women's participation in Europe. Institutional features such as child-related leave, the availability of childcare and the possibility to work part-time play an essential role in meeting the challenge faced by prime- 
age women to conciliate motherhood and professional life. With regard in particular to childrelated leave, this institution favours participation of prime-age women (25-54) if the leave is not too long -the effect becomes negative after 8 to 9 months. The participation rate of prime-age women is very important because it affects the participation behaviour of women aged 55-64. If the latter did not participate at an earlier age, they are not likely to participate at an older age.

In the second place, del Boca, Pasqua and Pronzato (2009) measure the impact of social and labour market policies (availability of part-time jobs, family allowances, childcare availability for children aged 0-2 and length of child-related leave) on participation and fertility decisions at the household level in 7 European countries (France, Belgium, Italy, Spain, Denmark, Netherlands and the United Kingdom). The authors focus on households with women aged between 21 and 45, married or living with a partner. Data comes from the 1999 wave of the European Community Household Panel.

According to the findings, the labour market policy measures are each significant for labour market participation. The availability of childcare significantly increases the probability of working. As for child-related leave, the length of the leave is positively related to participation initially, and then starts to decline. While legal entitlement to leave makes it easier for a woman to keep a formal attachment to her previous job, supporting employment, prolonged leave has the opposite effect, implying increasing difficulties in re-entering the labour market after childbearing.

Thirdly, de Henau, Meulders and O'Dorchai (2010) analyse the effect of various public policies designed to help out dual-earner couples with children (childcare provision, childrelated leave, and tax-cash benefits) on the full-time equivalent (FTE) employment rates of mothers (children aged 0-14), in comparison to non-mothers (no children under 15). For both groups, the article focuses on women aged 25-44 living with their partners. The scope of the study is the countries of the EU-15 around 2003. Data comes from the 2001 wave of the European Community Household Panel.

The article shows that when it comes to securing equal labour-market access and conditions for mothers of young children and non-mothers, public childcare provision has the strongest impact. Parental leave provision and cash support, on the other hand, tend to enlarge the 
motherhood-induced employment gap. As a result, the authors think that the main emphasis should be on elaborating sufficient, affordable, accessible, and high-quality public childcare provision. In their view 'countries should understand that as long as parental leave remains gender-biased (because parts of the leave are transferable and/or replacement rates are low), and so few fathers take their part of the leave, mothers will find it very difficult not only to stay in the labour market but also to pursue a promising and attractive career' (De Henau, Meulders and O’Dorchai, 2010, p. 65).

Finally, Erhel and Guergoat-Larivière (2013) study the effects of individual factors (for instance, education, spouse income and number of children) and institutional factors (childcare for very young children, child-related leave and working time regimes) in 2007 female employment rates of 22 EU Member States (Austria, Belgium, Czech Republic, German, Denmark, Estonia, Spain, Finland, France, Greece, Hungary, Ireland, Italy, Lithuania, Luxembourg, Latvia, Netherlands, Poland, Portugal, Sweden, Slovakia and United Kingdom) plus Norway and Iceland. The article distinguishes between the effects on all women and the effects on mothers of young children (under 3 years old).

For all women, the results show that formal childcare (childminder care or public childcare) and part-time work have a positive influence on women's employment probability. Conversely, informal childcare might on the whole lower women's employment probability. Child-related leave does not seem to have any effect on the individual employment status of women as a whole. Concerning mothers of young children (under 3 years old), public childcare and part-time work have a positive effect on their labour market participation, while child-related leave has a negative effect. Finally, childminder care and informal childcare were found to have no significant effect on mothers' likelihood of employment.

\section{Conclusions: towards a new paradigm in the European Union?}

The current design of child-related leave in EU law makes women much more likely than men to take leave. First of all, in the case of birth there is a consolidated EU standard of 14 weeks of maternity leave for mothers. As 14 weeks is just a minimum standard, at national level mothers may have a much longer maternity leave (e.g. 42 weeks in IE and 52 weeks in the UK). At the same time, there is no parallel EU right to paternity leave for fathers. However, most Member States currently provide for paternity leave, the duration of which is relatively short, e.g. 2 weeks in BE, IE and the UK. Secondly, in the case of adoption, as no 
EU right to adoption leave has been established, Member States may decide to regulate this leave in such a way that it is mainly the adoptive mother who makes use of it. Instead of a non-transferable individual entitlement of each adoptive parent, this leave may be designed as a family entitlement (ES) or as an entitlement of only one adopter (the UK and IE, in the latter case with a legal preference for the adoptive mother). Thirdly, EU law establishes a right to parental leave of 4 months to ensure the care of young children, natural and adopted, for both working mothers and fathers, but it does not encourage an equal take-up by women and men because only 1 month is non-transferable (the rest of the leave can be transferred to the other parent) and the payment of the leave is left to the discretion of Member States. As a result, mothers are more likely than fathers to take parental leave, including the transferable part from the father. Besides, as 4 months is only a minimum standard, women may in the end have an even longer parental leave (e.g. 16 months in BE and up to 3 years in ES).

The gendered use of leave has consequences on women's labour market outcomes. In terms of employment rates, most economic literature reveals the positive effect for women of relatively short leave. Conversely, when leave is too long the effects become negative, therefore reducing women's participation in the labour market. The turning point varies according to the different studies, ranging from 30 weeks (Akgunduz and Plantenga, 2013) to 8-9 months (Genre, Gómez Salvador and Lamo, 2010) to 2 years (Thévenon and Solaz, 2013). Concerning wages, economists agree that child-related leave has negative consequences on women's earnings, a penalty which increases notably with the length of the leave.

All things considered, the current design of child-related leave in EU law is making women much more likely than men to take leave, which in turn is helping to perpetuate the traditional role of women as child carers and creating detrimental effects for women in the labour market. Against this backdrop, the recent self-criticism of the European Commission is remarkable.

The pitfalls of the EU system of child-related leave have been acknowledged by the European Commission in its 2017 proposal for a Directive on work-life balance. Recital 8 of this proposal clearly states the current Union legal framework provides limited incentives for men to assume an equal share of caring responsibilities. Lack of paid paternity and parental leave in many Member States contributes to the low take-up of such leave by fathers. The 
imbalance in the design of work-life balance policies between women and men reinforces gender differences between work and care. The objective of this proposal is addressing women's under-representation in employment by correcting the unbalanced distribution of caring responsibilities between men and women. To do so, it creates a right to paternity leave for fathers of 2 weeks compensated at sick pay level (the same level as for maternity leave). In addition, it increases the non-transferable period of parental leave from 1 to 4 months and introduces compensation at sick pay level for parental leave in order to encourage fathers to take it up. As a drawback, the proposal does not include an individual and non-transferable right to paid adoption leave for each adoptive parent.

The Commission's Communication called EU Action Plan 2017-2019. Tackling the gender pay gap (COM (2017) 678 final) also refers to the inadequate work-life balance system in place. This Communication indicates that stereotypes persist about whether men and women should be on the labour market or at home and that such stereotypes are fuelled by inadequate work-life balance policies (p. 1). According to the Commission, these stereotypes are one of the root causes of the gender pay gap, which can be reduced by well-designed work-life balance policies. Investing in formal care facilities and in adequate family related leaves for both women and men contributes to reducing the gender pay gap, as it leads to fewer career interruptions and less discontinuous employment for women (p. 1).

The acknowledgment by the Commission of the unequal distribution of caring responsibilities between men and women and its consequences on the gender gaps in employment and pay is noteworthy. Currently women are facing most responsibilities related to childrearing alone. This makes it very difficult for them to compete on an equal footing with men in the labour market, thereby creating inequalities at work. The new measures proposed by the Commission to encourage men to get more involved in family life also deserve to be highlighted. Well-paid non-transferable periods of leave for fathers, by means of paternity leave or parental leave, may trigger the change to get men on board at home and to make a fairer labour market for women. The combination of non-transferability and adequate level of payment has proven to be the effective to increase the take-up rates by men, as shown by the experiences in Sweden and Iceland (Castro-García and Pazos-Moran, 2016, p. 60-62). In this sense, the old PLD 96/34 (which created for the first time unpaid leave for fathers), and the current PLD (which increased the unpaid leave from 3 to 4 months, and provided for 1 month on a non-transferable basis), albeit well-intentioned, have been 
ineffective to incentivise men to take-up leave due to the lack of remuneration. It seems that with the proposed Directive on work-life balance the Commission is finally moving towards a new paradigm with more equality at home and at work. An equal sharing of caring responsibilities is a fundamental prerequisite for more equality between men and women at work.

\section{Acknowledgments}

I would like to express my sincere gratitude to my $\mathrm{PhD}$ supervisors, to Professor Ángel Rodríguez García-Brazales, to my colleagues Jerome Saulnier, Vitalijus Novikovas and Halliki Voolma, to the Editor of the European Section, Professor Samantha Currie, and the anonymous reviewers of the Journal for their valuable input and advice. I also want to thank my friend Ricardo López Heredero for his continuous support.

\section{Notes}

1. Economic and cultural reasons explain why women keep on being the main takers of leave entitlements. Thévenon and Solaz (2013, p.16) explain the key economic rationale: 'as leave payments do not fully replace the leave-taker's wage, and since women often earn less than their partners, they are still more likely than men to take up all, or most, of the leave entitlement'. Cultural patterns also explain the current situation, as in many countries women continue to be expected to fulfil the traditional role of child carers.

2. The legal situation described in this article refers to Great Britain. Northern Ireland has its own legislation, which will not be addressed here.

3. ES official statistics show that fathers benefited from the maternity allowance in 2017 in less than $2 \%$ of cases: http://www.segsocial.es/Internet_1/Estadistica/Est/Otras_Prestaciones_de_la_Seguridad_Social/Materni $\underline{\mathrm{dad} / 229796 .}$

4. Several studies show the low take-up of the shared parental leave scheme in the UK: (https://www.eurofound.europa.eu/observatories/eurwork/articles/united-kingdom-lowtake-up-of-shared-parental-leave-scheme).

5. The assumptions are: many firms; perfect information about wages and job conditions; firms are offering identical jobs; many workers with the same skills (https://www.economicshelp.org/labour-markets/wage-determination/).

6. Ruhm (1998, p. 289); report from the Commission on the implementation of Council Directive 92/85/EEC of 19 October 1992, on the introduction of measures to encourage 
improvements in the health and safety at work of pregnant workers and workers who have recently given birth or are breastfeeding [Brussels, 15.03.1999, COM(1999) 100 final, p. 21]; and Palma Ramalho, Foubert and Burri (2015, p. 18).

\section{References}

- AKGUNDUZ, Y.E. and PLANTENGA, J. (2013), Labour market effects of parental leave in Europe, Cambridge Journal of Economics, 37(4), 845-862

- BARNARD, C. (2012), EU Employment Law, Oxford, Oxford University Press

- BECKER, G.S. (1965), A theory of the allocation of time, The Economic Journal, 75(299), 493-517

- BLUM, S., KOSLOWSKI, A. and MOSS, P. (eds.) (2017), $13^{\text {th }}$ International Review of Leave Policies and Related Research 2017, retrieved January 2018 from http://www.leavenetwork.org/fileadmin/Leavenetwork/Annual_reviews/2017_Leave Review_2017_final2.pdf

- BURRI, S. and VAN EIJKEN, H. (2014), Gender Equality Law in 33 countries. How are EU rules transposed into national law?, European Commission

- CARACCIOLO DI TORELlA, E. (2007), New Labour, New Dads - The Impact of Family Friendly Legislation on Fathers, Industrial Law Journal, 36, 318-328

- CARACCIOLO DI TORELLA, E. (2014), Brave new fathers for a brave new world? Fathers as caregivers in an evolving European Union, European Law Journal ,20(1), 88-106

- CASTRO-GARCÍA, C., and PAZOS-MORAN, M. (2016), Parental leave policy and gender equality in Europe, Feminist Economists 22(3), 51-73

- CURRIE, S. (2013), Men on the sidelines: the reconciliation of work and family life agenda in the context of cross-border posting, Journal of Social Welfare and Family Law, 35(3), 398-408

- DE HENAU, J., MEUlDERS, D. and O'DORCHAI, S. (2010), Maybe baby: comparing partnered women's employment and child policies in the EU-15, Feminist Economics, 16(1), 43-77

- DEL BOCA, D., PASQUA, S. and PRONZATO, C. (2009), Motherhood and market decisions in institutional context: a European perspective, Oxford Economic Papers, 61(suppl_1), i147-i171

- DORMAN, P. (2014), Microeconomics: a fresh start, Berlin, Heidelberg, Springer Berlin Heidelberg 
- ERHEL, C. and GUERGOAT-LARIVIÈRE, M. (2013), Labor market regimes, family policies, and women's behavior in the EU, Feminist Economics, 19(4), 76-109

- FRANK, R.H. (2008), Microeconomics and behavior, Irwin, Boston

- GENRE, V., GÓMEZ SALVADOR, R. and LAMO, A. (2010), European women: why do(n't) they work?, Applied Economics, 42(12), 1499-1514

- HANEL, B. (2013), The impact of paid maternity leave rights on labour market outcomes, Economic Record, 89(286), 339-366

- JACOBI, L., WAGNER, H. and FRÜHWIRTH-SCHNATTER, S. (2014), Bayesian treatment effects models with variable selection for panel outcomes with an application to earnings effects of maternity leave, IDEAS Working Paper Series from RePEc, Working Paper No. 1412

- MASSElOT, A., CARACCIOLO DI TORELlA, E. and BURRI, S. (2013), Fighting discrimination on the grounds of pregnancy, maternity and parenthood. The application of EU and national Law in practice in 33 European countries, European Commission

- PAlMA RAMAlHO, M. do R., FOUBERT, P. and BURRI, S. (2015), The implementation of parental leave Directive 2010/18 in 33 European countries, European Commission

- PINDYCK, R.S. and RUFINFELD, D.L. (2013), Microeconomics, Boston, Pearson

- RAMÍREZ BUSTAMANTE, N., TRIBIN URIBE A.M. and VARGAS, C.O. (2015), Maternity and labour markets: impact of legislation in Colombia, IDEAS Working Paper Series from RePEc, No. 870

- RØNSEN, M. and KITTERØD, R.H. (2015), Gender-equalizing family policies and mothers' entry into paid work: recent evidence from Norway, Feminist Economics, 21(1), 59-89

- RUHM, C.J. (1998), The economic consequences of parental leave mandates: lessons from Europe, The Quarterly Journal of Economics, 113(1), 285-317

- SCHEUBEL, B. (2014), Does it pay to be a woman? Labour demand effects of maternity-related job protection and replacement incomes, IDEAS Working Paper Series from RePEc, No. 685

- SCHÖNBERG, U. and LUDSTECK, J. (2014), Expansions in maternity leave coverage and mother's labor market outcomes after childbirth, Journal of Labour Economics 32(3), 469-505 
- THÉVENON, O. and SOLAZ, A. (2013), Labour market effects of parental leave policies in OECD countries, OECD Social, Employment, and Migration Working Papers, 141

- WELDON-JOHNS, M. (2011), The Additional Paternity Leave Regulations 2010: a new dawn or more 'sound-bite' legislation?, Journal of Social Welfare and Family Law, 33(1), 25-38 